\title{
SEMIOTIC COMMUNICATION: AN APPROACH OF UNDERSTANDING A MEANING IN COMMUNICATION
}

\author{
Ibrahim \\ ab_irhamiy@yahoo.com \\ Departemen of Comunication and Islamic Brodcasting in IAIN Pontianak \\ Sulaiman \\ sulaiman@iainptk.ac.id \\ Departemen of Islamic Education in IAIN Pontianak
}

\begin{abstract}
In interpreting communication, we are often trapped in symbols and a set of signs that are used. This is due to our simple assumption that tends assume on symbols or signs that stand alone in representing meaning. We forget that symbols or signs, as well as meaning are complex. Though they are not stand alone. They are representation of the many factors that influence them, including the knowledge and culture of their participants. In media, the meaning of symbols or signs that used to convey news is very dependent on the ideology of the media and the whole organization that manages the media. Even the "reality of truth" is very dependent on the construction of the media in processing it. Likewise in film and music, certain symbols or signs that are used are representations of reality which must be explored and understood as a form of communication, even a picture of the social and cultural reality of the participants. This is where the semiotics in communication emerge, and offer themselves as an important approach in understanding the true meaning of symbols or signs used in a communication process.
\end{abstract}

Keywords: Reality ; Media ; Symbols ; Signs ; Semiotic Communication.

\section{INTRODUCTION}

You shine like light that always gives me light (Bersinar kau bagai cahaya yang selalu beriku penerangan). As soft as the image of your love, I always feel in joy and sorrow (Selembut citra kasihmu kan selalu kurasa dalam suka dan duka).

You are my mother my love (Kaulah Ibuku cinta kasihku).

Thank you, I will never stop (Terima kasihku takkan pernah terhenti).

You're like the sun that always shines

(Kau bagaikan matahari yang selalu bersinar).

Shining my life with your warmth

(Sinari hidupku dengan kehangatanmu). 
Like the dew of this coolness of heart, with your affection (Bagaikan embun kesejukan hati ini, dengan kasih sayangmu). How meaningful you are and you will never be replaced for me (Betapa kau sangat berarti dan bagiku kau takkan pernah terganti)... (The Mother by Haddad Alwi feat Farhan)

The above paragraph is not just stanzas of song lyrics accompanied by music. However, there are many messages and eemeanings that they brings with the text and lyrics of the song. It even involves all the feelings, emotional and psychology of its creators, singers and listeners. Because it's no wonder a song can bring someone's mood, thoughts and feelings to dissolve with it. Text, lyrics, and music are sign packages that contain many messages and meanings in communication.

By means of signs, humans can think because without a sign we cannot communicate. Because communication always occurs with the mediation of signs, where the signs are the basis of all communication, and semiotics is the most instrumental approach in the study of sign communication (Alex Sobur, 2004)

The statement above gives the impression that semiotics has become one of the important sciences in the dynamics of the development of scientific methodology that is consistent and unique in the study of communication. Therefore, We find that semiotic analysis appears immediately after / together with other communication text analysis methodologies such as content analysis and discourse analysis.

As a characteristic feature (characteristics) of research in the field of Communication Studies, the study of text messages (content analysis, discourse analysis to semiotic analysis) is actually still very minimal to do, especially in the Islamic Communication and Broadcasting Study Program (KPI) IAIN Pontianak at that time. For IAIN Pontianak environment itself, the approaches of Communication science such as this approach has only begun to be introduced and promoted in the past decade to students in the KPI Study Program through the Communication Research Methodology course. This fact also shows that the application of this new approach in communication studies, especially in IAIN Pontianak of KPI Study Program is not as easy as imagined. In 2013, only one research / undergraduate thesis title could be produced by KPI students with the Semiotic Communication Study approach. There are many factors being the reasons. One of the main factors is the absence of examples / pioneers of this study at the local level (lecturers and students), especially with the semiotic analysis approach.

Andi Eva's success in completing her undergraduate thesis using the communication semiotics approach at that time became a new spirit, or even a model for the conducting of other next undergraduate thesis research using semiotics. And since then, slowly but surely, the semiotic approach has become increasingly popular for students and used in conducting the thesis in the Islamic Communication and Broadcasting Study Program IAIN Pontianak. As a new science, or just beginning to be introduced in the last decade, the students in the KPI Study Program should be encouraged and seriously guided to be able to apply this semiotic analysis approach in the final research (thesis), as well as content analysis and analysis the discourse that had already begun. The hope is that semiotics as an approach to communication studies can be more attractive and interesting for students in the Islamic Communication and Broadcasting Study Program. Since it was first introduced at IAIN Pontianak, and applied in the writing of students' thesis in the last decade, it 
must be admitted that the quality is still very low and simple. However, that is the effort that must be done, and that's how the policy should be in the context of developing Communication Studies, especially in this case for the development of communication research methodologies.

This article is actually a modification and adaptation of a simple paper that the author made to assist student guidance in completing a thesis in the Islamic Communication and Broadcasting Study Program six years ago. There is an academic anxiety that the writer feels related to the weak ability of academics in developing the communication study methodology at that time. Therefore, the writer thinks that there is a need for a serious initial effort to encourage and help KPI students getting better understanding about semiotic analysis as an important approach in understanding the text / meaning of communication. As the hope, those interested in studying communication science have a reference and enthusiasm to continue in developing communication studies, especially students are able to apply it in their final research (undergraduate thesis).

\section{UNDERSTANDING SEMIOTIC}

Semiotics is a science or method of analysis to study signs, in the form of devices or symbols that we use in human relations (Henny, 2014). Therefore, Communication Semiotics is an approach and analytical method used to understand the signs in the communication process, which includes six elements of communication which include the sender, recipient of the code or sign system, messages, channels, and references / things being discussed (Jakobson, 1963 in Alex Sobur, 2004: 15).

Besides the term of Semiotics, there are some experts who use the term semiology. The use of these two terms in principle does not bring fundamental differences in intent. The use of these two terms tend gives the scholars for the identity of the pioneers of the study of this sign. Semiology, for example, is widely used by those who adhere to the European school (French) with the main character Ferdinand de Saussure (1857-1913) that his principal and main point of view in semiotic analysis is grouping of symbols to two kinds; signifier-the concept and signified-the secondimage. Signifier refer to physically of the symbols from symbols such as utterance, pictures or painting. On other hands, signified refer to mental aspect of symbols or associative view about symbols (Malone, in Pawito 2007: 162). Including Roland Barthes (1915-1980), who is known as the next figure who gives this semiology approach a more perfect concept with the concept of connotation and denotation (See Pawito, 2007: 163-164). While the term semiotics refers more to American traditions / traditions pioneered by Charles Sanders Peirce (1839-1914) (see Yakin \& Totu, 2014). Although in its development, the term semiotics is more widely used because it is considered to cover more aspects of the practical study of the sign itself compared to semiology which tends to be theorizing the science of sign.

While the term semiotics which beginning appeared at the end of the 19th century by the American pragmatic philosopher (Charles Sanders Peirce) refers to the formal doctrine of signs which includes language and sign systems in communication (see Moratta, 2017). According to him, language itself is the most fundamental sign 
system for humans, while nonverbal signs such as gestures, forms of clothing, and various other conventional social practices can be seen as a kind of language composed of meaningful signs that are communicated based on relations relations (Alex Sobur, 2004: 13). According to van Zoest (1993), semiotics or semiology is a very important science in human communication, because human life always requires signs and symbols. Here we find several terms that show the close relationship of humans with signs or symbols as the term homo semioticus in van Zoest (1993), or homo symbolicum in the philosophical discourse of humanism, or animal symbolicum in Erns Cassirer and Susanne Langer (Nuerhadi in Alex Sobur, 2004: 14). Although in their journey, these two terms have led to a separate debate among semioticians who think that the use of the term animal for humans is an insult / humiliation, and that is different from the term homo.

The reality of the debate actually does not reach the scientific substance of Semiotics itself. This is proven by the development of this science as a method of scientific research, especially in the study of the interpretation of symbols or media texts until nowadays. This dynamic eventually creating various efforts to apply the semiotics research methodology in communication studies.

\section{SEMIOTIC IN COMMUNICATION SCIENCE}

In the study of communication, semiotics is an important science, because signs are the main basis of all communication (Littlejohn, 1996). With signs humans can do any communication with each other (Alex Sobur, 2004: 15). In its development, the study of semiotics developed into two main classifications, namely Communication Semiotics and Signification Semiotics (see Eco, 1979; and Hoed, 2001). Semiotics Communication emphasizes the theory of sign production, one of which assumes the existence of six factors in communication (sender, receiver, message, channel and reference). Whereas Semiotic Signification puts emphasis on sign theory and its understanding in a particular context (Alex Sobur, 2004: 15). This is where the emergence of various branches of semiotic studies such as Animal Semiotics (zoomsemiotics), Medical Semiotics (medical semiotics) and others, according to Eco (1979) reaching 19 fields of study (see in Sobur, 2004: 109).

\section{SEMIOTICS IN COMMUNICATION STUDIES}

The word semiotics itself comes from the Greek semeion which means sign (Sudjiman and Van Zoest, 1996), or seme which means interpreter of sign (Cobley and Jansz, 1999), or what is commonly understood as a sig by which something in known or a sign where something can be known (John Lock, 1960). Semiotics is rooted in classical and scholastic studies of the art of logic, rhetoric and poetics (Kurniawan, 2001). "Sign" at that time still means something that points to the existence of something else, for example, smoke marks the existence of fire (Alex Sobur, 2004: 17). 
If they applied to language signs, letters, words, and, sentences, they do not have any meaning in communication. These signs will have meaning when interpreted by the sender (the signer) and the reader (the recipient of the sign). The reader (receiver of the sign) is what connects the sign with what is signified (signifies) in accordance with the conventions in the language system in question (Adham, 2012). No wonder the communication experts agree with the words don't mean people mean, an acknowledgment that words are not meaningful, but the people who give meaning to those words.

\section{SEMIOTIC ANALYSIS IN COMMUNICATION RESEARCH}

\section{PRINCIPAL DEFINITION AND THE CHARACTER}

Simply, we can conclude that semiotic analysis (semiotic analysis) is a way or method for analyzing and giving meanings to message symbols or text packages in all its forms (sign), both on mass media and other documents / texts (Pawito , 2007: 155). In other words, the analysis of semiotics works to trace the meanings which are transported by the text in the form of symbols (signs), where the text is the focus of analysis in semiotic research.

As a scientific method, semiotic analysis is not only relatively new, but has a very broad field of study, because of that Eco (1979) provides three limits to semiotic research namely "the cultural realm", "the realm of nature", and "the epistemological realm". The realm of culture concerns the relationship of signs and the meaning of signs based on the cultural values of a society. The realm of nature involves the relationship of signs and meaning of signs based on natural values in a community environment. And the epistemological realm concerns the relationship of signs and the meaning of signs based on knowledge that continues to develop in a society.

The extent of this study covers communication processes that appear more natural and spontaneous to complex cultural systems. Therefore, according to Eco (1979), no less than 19 fields are considered as study material for semiotics, namely: animal semiotics (zoom semiotics), olfactory signs, tactile communication, code of deception (code of code) taste), paralinguistic, medical semiotics, kinesics and proxemics, musical codes, musical codes, formalized languages, written languages, unknown alphabet, secret codes (written languages, unknown alphabets, secret codes), natural languages, visual communication, system of objects, plot structure, text theory, codes culture (cultural codes), aesthetic texts (aesthetic texts), mass communication (rhetoric) and rhetoric.

In all forms of this application, the symbol of the subject of analysis (unit of analysis) according to Pierce (in Pawito, 2007: 158-159) is divided into three categories, namely icons (icons), indexes (index), and symbols (symbols). The icon is a symbol that is determined (how to interpret it) by a dynamic object because of the internal properties that exist (a sign which is determined by the dynamic object by virtue of having own internal nature), although usually the object to which the reference is not present. Matters such as resemblance, conformity, imitation, and impressions or images are keywords to provide meanings for iconic symbols. In other words, an icon is a physical object (two or three dimensions) that resembles what is 
represented (similarity). For example, Megawati's photo is a Megawati icon, Amin Rais's picture is an Amin Rais icon (Alex Sobur, 2004: 158).

According to Zoest (in Sobur, 2004), icons can be explained in three forms; 1). Spatial or topological icons, which are marked by the similarity between the room / profile and form of the text with what is used as a reference; 2). Relational or diagrammatic icons in which there is a similarity between the relationships of two textual elements with the relationship of two elements of reference; 3). The metaphor icon, where the relationship is seen no longer because of the similarity between the sign and the reference, but between the two references, both of which are referred to by the same sign, which is direct and indirect. In the context of art, metaphor icons (according to Dahana, in Sobur, 2004) usually appear in the form of parables, allegories or metaphysical stories.

While the index refers to the symbol whose meaning is determined more by dynamic objects by being in a real relation to it (the real connection with it). The meaning process is not direct, but rather by linking the meaning. Examples of smoke are always associated with fire, crying is associated with sadness, and so on. The index can also be seen in other examples, for example the word cigarette which has a smoke index, where the indexional relationship between cigarettes and smoke occurs because there is a permanent characteristic relationship between smoking and smoke. Words that have an indexional relationship each have their own main characteristics that are different from each other and cannot replace each other as cigarettes with smoke having different main characteristics (see in Alex Sobur, 2004: 159).

The symbol itself in semiotics is usually understood as a sign which is determined by its dynamic object only in the sense that it will be interpreted (a symbol that is determined by its dynamic object in the sense that it must be completely interpreted). The intended interpretation is an attempt to make sense of symbolic symbols by involving elements of the learning process, based on social experience and community agreement about the meaning of the symbol. For example, the flag is agreed upon as a symbolic symbol of a nation, which is why all citizens pay respect to it. See further explanation in Pawito (2007), Alex Sobur (2004).

In many cases, we often consider symbols with that sign to be the same. Though both are different. Where the sign is directly related to the object, while the symbol requires a more intensive meaningful process after connecting him with the object. In other words symbols are more substantive than signs. In the context of the sign, the cross which is displayed in the church becomes the identity as a place of worship for Christians. While as a symbol, the cross is a symbol of respect for the sacrifice of the body and soul of Christ for humanity (Alo Liliweri, 2001: 296).

The following is a brief description of the application of semiotic analysis in various fields and objects of study in the discipline of Communication Studies, which includes mass media reporting, advertising communication, nonverbal signs, films, comics, cartoons, literature, and music.

\section{SEMIOTIC ANALYSIS IN MASS MEDIA}

Basically, the study of mass media includes the searching for messages and meanings in the material (the contents of the text), because actually the semiotics of communication - as well as the basis of the study of communication science -, is a communication process that is essentially a search for meaning. In other words, we 
study media is to learn meaning; Where does it come from, like what, what is its purpose, how is it delivered, and how do we (the reader) give (interpret) its meaning (Alex Sobur, 2004: 110).

In printing media, the study of semiotics also mostly investigates the ideology behind the media coverage. Therefore the questions appeared include; how does the press talk about this group and so on? How was the group portrayed by the media / press? How do the media / press treat this and that problem? All of these problems in the study of communication semiotics can be done with quantitative and qualitative analysis techniques, of course, with all the advantages and disadvantages each of them.

The main question when applying the semiotic communication approach in studying media is how the contents of the media should be explained? Or, when the media reports an event with a certain orientation, how do we explain it? This is where McNeir (1994) in Sudibyo (2001) offers three main approaches, namely the politicaleconomic approach (organizational political approach), organizational approach and cultural approach.

The political-economic approach holds that media content is more determined by economic and political forces outside media management (external factors). These strengths include media owners, financiers and media revenues. This factor is believed to be more decisive about what news / events can and cannot be displayed / reported in the media.

The organizational approach argues for the opposite of economic politics above. This approach holds that the media management organization determines the process of forming and producing news through work practices, professionalism, organizational rules and mechanisms in the editorial room (internal factors). Media ideology is part of this factor, where it will be reflected in the overall value that is the basis of the work of media management organizations. Media ideology will also ultimately become a reference and basic value for all managers (media organizations) in determining (choosing) which news is appropriate and not suitable for publication, in what form and manner in which a news should be published, etc. This is where the media appears more as a "formulator of reality" (definer of reality) as the underlying ideology, rather than a "mirror of reality" (mirror of reality) (see Alex Sobur, 2004)

The cultural approach holds that media coverage is determined by the two factors above (external and internal) simultaneously. The media basically has a mechanism to determine organizational patterns and rules. But with these various patterns, the meaning of events cannot be separated from political-economic forces outside the media.

Through the sign, analysis of semiotics in the media also see how the relationship between media owners with social constructs (reality) are built through media coverage. Theoretically, the mass media aims to convey information correctly effectively and efficiently. However, in practice, often what is called truth is determined by the many interrelationships of the survival media itself, both in business and political terms. Even according to Budi Susanto (1992) as quoted in Alex Sobur (2004), "the real truth is that of the company". It is in the name of truth that reality is displayed by the media, which is not only delayed reality, but also edited reality. 


\section{SEMIOTICS ANALYSIS ON FILM}

Research on films or other forms of narrative audio-visual stories can be done by choosing one particular semiotic analysis model (Pawito, 2007: 155-156). How semiotic analysis is applied to a film, Aditia S. Hapsari's (2005) study that studies the Kalyana Shira Film (in collaboration with Cinekom) film production of the Unfinished Violin film can be used as an example in this study (see Pawito, 2007: 165-167).

Using Roland Barthes's semiotic analysis, Hapsari examines the meaning of the symbols contained in the film. The impression with the study is that the film, directed by Sekar Ayu Asmara (and screenwriter) is full of moral messages, especially love with varied contexts, such as love for others, love between two people of different sexes, love in the context of mother and child, and love for all of God's creatures in the form of animals and plants.

Semiotic analysis of the film shows the value of love for fellow human beings symbolized by scenes of central figures (Bhisma, Renjani and Mbak Wid) who want to care for Gods and other handicapped children at the True Mother Orphanage with sincerity and affection, even though people concerned parents have thrown them away. Then love in the general sense between a man and a woman can be understood from the symbol of the romantic relationship of love between Bhisma (played by Nocholas Saputra) and Renjani (played by Ria Irawan). Love for fellow creatures created by God can be understood from the symbol of Renjani's attempt to catch a butterfly without hurting or hurting it.

In addition, the 90-minute film also carries another moral message, namely rigidity and honesty. This is symbolized (signed) by Renjani who is so tough in living life with commendable actions - setting up an orphanage to accommodate children with disabilities and thrown away from their parents, even though she herself is a woman victim of rape and having an abortion (See Pawito, 2007) .

The above example gives a form of meaning of a message in a film through signs. Films (according to van Zoest, 1993) are generally built with many signs, where the signs (including various sign systems) work well together in an effort to achieve the expected effects, especially in the form of images and sounds (see in Alex Sobur, 2004: 128).

\section{SEMIOTICS ANALISIS ON MUSIC}

What can we examine in music that adheres to the auditive sign system. Art van Zoest (1993) provides three possible ways to do a semiotic analysis of music, as quoted in Alex Sobur (2004: 144-145).

First, to consider the structural elements of music as iconic for the listener's neurophysiological symptoms. Thus, the rhythm of music can be associated with biological rhythms. Secondly, to consider structural phenomena in music as iconic to the structural phenomena known in the world of appreciation. Third, to look for the musical denotatum towards the content of responses and feelings raised by indexical music.

For Zoest, the indexical nature of this musical sign is the most important possibility, because symbolism is also a form in music, both in terms of type, historicity, and style, which are always a complex part expressed in music. Through signs (syntax, semantic and expressive), we can not only recognize the message / meaning conveyed in music, but also can recognize one's feelings (happiness, sadness, 
and so on) through music. See an example of Zoest's analysis in Sylado (1977) interpreting signs of sadness through the 60s American pop song Crying in the Rain, the big hit Everly Brothers (Alex Sobur, 2004: 146). The analysis found that there are words of heartbreak or sadness that are tried to be sung through the song, where the words (as a sign) no longer merely express feelings (sadness and heartbreak), but also reflect on those feelings. in the lyrics of the song also found an attempt to find a way out of feelings of sadness, such as "dispel tears by welcoming the storm" (look for stormy weather to hide the tears), and "put on a smile while walking in the hot sun" to ward off tears (wear a smile and walk in the sun).

As a symbolic process, Alan P. Marriam through his book Anthropology of Music emphasizes the importance of the study of the function of music in society. According to him, music symbolism and its functions can be assessed through aspects of instrumentation, word of songs, native typology and classification of music, roles and status of musicians, function of music in relation to other aspects of culture and music as creative activity (Bandem dalam Alex Sobur, 2004: 147). This view believes that the message / the deepest meaning in music can be found by analyzing the signs (signs) in the form of musical instruments / rhythms, the words sung, the classification and type of music, the role and status of musicians, and the function and relationship of music with other aspects of music culture and creativity in a society. Because of that James Lull (in Alex Sobur, 2004) concluded that music is a cultural domain, where cultural power is exercised.

Music is also actually a representation of our people's lives, because music is an expression of one's feelings and hearts. In a song, music (lyrics and sair) actually brings meaning to the feelings, moods and background of the singer (songwriter). Based on the workings of this communication semiotics, we can understand the meaning contained in music (Gibraltar, 2014). Andi Eva (2013) for example, examines the message of preaching in the lyrics of the song Assalamu'alaikum, the the best work of Opik. In short, understanding the community and its feelings can be done, among others, through the study of music, as studying music can also provide an overview of the community and the feelings of the people around them. That's the belief in the semiotic analysis of communication in music. Until now, Thesis Andi Eva is the only research result (thesis) of students in the KPI Study Program of the Da'wah Department of STAIN Pontianak who use the Semiotic analysis approach (semiotic analysis). Although as a novice researcher and the only one at STAIN Pontianak, as a joint advisor Mr. Acan Mahdi, we gave him high appreciation, encouragement and enthusiasm, from the beginning of writing to producing good (thesis) works and were quite proud of the Semiotic Communication analysis approach. For more details, please read the thesis of Andi Eva (2013).

\section{CONCLUSION}

In principle; words, symbols, symbols or any signs in communication do not have a definite meaning. But humans (who use it) give meaning to words, symbols, symbols or whatever the sign is. Words don't mean people means, communication axioms assert.

While on the other hand, communication is something that must happen and inevitable in our social relations as in the axioms, we can't not to communicate. 
Where in the process of communication, symbols, symbols or signs become important factors in the exchange of meaning / messages or intentions to communicate. Therefore, understanding symbols, symbols and a set of signs in communication becomes something that is necessary (absolute) to find meaning / message. In this case, semiotic analysis becomes one of the important sciences that must be mastered, in addition it is for other analyzes in understanding the meaning / message in the discipline of communication, especially media texts. Finally, hopefully a brief theoretical perspective on the analysis of semiotics as an approach to understanding the meaning of text in communication can help the understanding of practitioners of communication studies and research in understanding meaning in communication in the future, amen.

\section{ABOUT THE AUTHORS}

Ibrahim; is a Senior Lecturer (Associate Professor) at State Islamic Institute of Pontianak. He is lecturer for some courses such as Intercultural communication, and communication and Islamic Brodcasting. He is doctoral from Institut Alam and Tamaddun Melayu (ATMA) Universiti Kebangsaan Malaysia (UKM) 2013.

Sulaiman; is a lecturer at State Islamic Institute of Pontianak. He is english lecturer and graduated from Sebelas maret University Solo. He is interested in research of education

\section{REFERENCES}

Adham, Sarah Ahmed. (2012). A Semiotic Analisys of The Iconic Representation of Woman in the Middle Eastern Media. Dissertation in the University of Birmingham.

Alex Sobur. (2004). Semiotika Komunikasi. Cetakan Kedua. Bandung: Remaja Rosdakarya.

Alex Sobur. (2004). Analisis Teks Media: analisis wacana, analisis semiotika dan analisis Framing. Bandung: Remaja Rosdakarya.

Alo Liliweri. (2001). Gatra-Gatra Komunikasi Antarbudaya. Jogjakarta: Pustaka Pelajar.

Andi Eva. (2013). Analisis Semiotika Pesan Dakwah dalam lirik lagi Assalamu alaikum karya is the best Opik. Skripsi, Jurusan Dakwah STAIN Pontianak, Program Studi Komunikasi Penyiaran Islam.

Dedy Mulyana. (2003). Metodologi Penelitian Kualitatif. Bandung: Remaja Rosdakarya

Gibraltar, Muhammad. (2014). A Semiotic Analisys of the Video Music "Indonesia Bangkit": Comparing Audience Interpretation. Humanities and Social Sciences, 2 (6), 148-156.

Heny Uswatun Hasanah. (2014). A Study of Signs: ThePolitical Adverstisments in Presidential Election Campaign of Indonesia 2014 Bases on the Peire`s Theory. OKARA, Vol. 1, Th 9, May. 
International Journal of Media and Communication Research

Volume 1 (1) 2020

Litlejohn, Stephen W. (2002). Theories of Human Communication. Five Edition. Belmont CA: Wadsworth

Marotta, Anna. (2017). Visual Image and Languange Architecture: Signifier Semiotics and Meaning Semiotics. Proceding the International and Interdiciplinary conference IMMAGINI, Brixen- Italy, 27-28 November.

Pawito. (2007). Penelitian Komunikasi Kualitatif. Jogjakarta: LKiS Pelangi Nusantara.

Thesis: Jurnal Penelitian Ilmu Komunikasi. Departemen Ilmu Komunikasi, Fisip UI. Volume III/No.2 Mei-Agustus 2004.

Yakin, Haline Sendera Mohd; Totu, Andreas. (2014). The Semiotic Perspectives of Pierce and Soussure: A Brief Comparative Study. The International Comference on Communication and Media (i-COME`14) Langkawi- Malaysia. ProcediaSocial and Behavior Science 155 (2014), 4-8. 